\title{
Pretreatment with levosimendan improves outcome in off-pump coronary artery bypass grafting
}

\author{
I Husedzinovic, N Bradic \\ From 23rd World Congress of the World Society of Cardio-Thoracic Surgeons \\ Split, Croatia. 12-15 September 2013
}

\section{Objective}

Levosimendan, calcium sensitizer, induces contractility by binding to troponin $\mathrm{C}$ without increasing intracellular calcium concentration. We tested the hypothesis that levosimendan could produce early and prolonged beneficial effect on left ventricular (LV) systolic function in patients with normal LV function undergoing off-pump coronary artery bypass grafting (OPCABG).

\section{Methods}

Loading dose of levosimendan at low-dose $(12 \mathrm{mcg} / \mathrm{kg})$, high-dose $(24 \mathrm{mcg} / \mathrm{kg})$ or placebo were administered in thirty-one patients in randomized controlled study. Bolus thermodilution by pulmonary artery catheter used for cardiac output $(\mathrm{CO})$ measuring. Numerical data were described by median. To compare the three independent groups (low or high-dose levosimendan or placebo) the Kruskal-Walis test was applied. For comparing time points in one group, we tested the differences in time within each group with the Friedman test.

\section{Results}

Significant increase in $\mathrm{CO}$ occurred after low-dose $(\mathrm{p}=0.001)$ and high-dose levosimendan $(\mathrm{p}<0.001)$. CO was higher in all measurements in patients receiving low-dose levosimendan versus patients received placebo, but didn't rich significance. In patients receiving low-dose levosimendan, compared with baseline measurement, $\mathrm{CO}$ was higher 20 minutes after infusion $(\mathrm{p}=0.080)$ and $48 \mathrm{~h}$ after surgery $(\mathrm{p}=0.067)$. Similar alteration in $\mathrm{CO}$ measurements occurred after high-dose comparing with low-dose levosimendan. Furthermore,

\footnotetext{
* Correspondence: nbradic@kbd.hr

Clinic of Anesthesiology, Reanimatology and Intensive Medicine, University Hospital Dubrava, Zagreb, Croatia
}

(c) 2013 Husedzinovic and Bradic; licensee BioMed Central Ltd. This is an Open Access article distributed under the terms of the Creative Commons Attribution License (http://creativecommons.org/licenses/by/2.0), which permits unrestricted use, distribution, and reproduction in any medium, provided the original work is properly cited.

\section{( Biomed Central}

\section{and take full advantage of:}

- Convenient online submission

- Thorough peer review

- No space constraints or color figure charges

- Immediate publication on acceptance

- Inclusion in PubMed, CAS, Scopus and Google Scholar

- Research which is freely available for redistribution

Submit your manuscript at www.biomedcentral.com/submit
$\mathrm{CO}$ was significantly higher in patients receiving highdose levosimendan compared with those receiving placebo, 20 min after infusion $(\mathrm{p}=0.021)$ and $48 \mathrm{~h}$ after surgery $(\mathrm{p}=0.006)$. Compared with baseline measurement, all values of $\mathrm{CO}$ were significantly higher in patients treated with high-dose levosimendan $(\mathrm{p}=0.005$

\section{Conclusion}

Levosimendan produces early and prolonged beneficial effect on left ventricular performance in patients with preoperative normal LV function undergoing OPCABG

doi:10.1186/1749-8090-8-S1-0159

as: Husedzinovic and Bradic: Pretreatment with

improves outcome in off-pump coronary artery bypass 